\title{
BUILDING A STRONG CUSTOMER-BRAND RELATIONSHIP FROM CBBE
}

\author{
Liang Qiao* \\ Sichuan Technology and Business University, P.R.China \\ Hui Wang \\ Sichuan Technology and Business University, P.R.China
}

\begin{abstract}
As business competition gets more and fiercer, corporate competition accordingly escalates from parts to the whole. On top of it comes the brand competition, and plays a crucial role in the process. This article cited Olin's description and gives a detailed discussion on the elements of Keller's (1993) Customer-Based Brand Equity (CBBE) pyramid model. In addition, we give a thorough analysis based on a number of applications of the above model. Finally, a detailed analysis is included in the end of essential elements of the model; and the brand community is referred to build and measure the customer-brand relationship.
\end{abstract}

Keywords: brand, brand equity, CBBE, brand community

\section{JEL code: M31}

\section{Introduction}

All successful businesses need to own three key elements: technical, financial and ability to sell (or seduction) (Olins, 2003a). Branding, as a means to seduce people into purchasing, can be included in the ability-to-sell element. In recent years, corporate competition is escalated from parts to the whole, meaning from products to brands; so brand will play a very important role in the $21^{\text {st }}$ century.

When the importance of brand and branding was recognised, research was started and a number of definitions were made and cited (e.g. Cowley, 1991; Kotler 2000; Keller, 2003; Olins, 2003a). The usual definition was referred by American Marketing Association (AMA): a brand is "a name, term, sign, symbol, or design, or a combination of them, intended to identify the goods and services of one seller or group of sellers and to differentiate them from those of competitors" (www.marketingpower.com). According to Keller's (1993) Customer-Based Brand Equity (CBBE) pyramid model (see Figure 1), which can be used to measure or build strong brands, the definition of AMA reflects brand salience, which can differentiate products and build brand awareness and knowledge (Pennington and Ball, 2009). This elementary definition only shows some superficial understanding of brand and branding, but brand development and brand competition will depend on deeper understanding. The CBBE could help us obtain better understanding of brand connotation, which can be used to building a strong customer-brand relationship. 


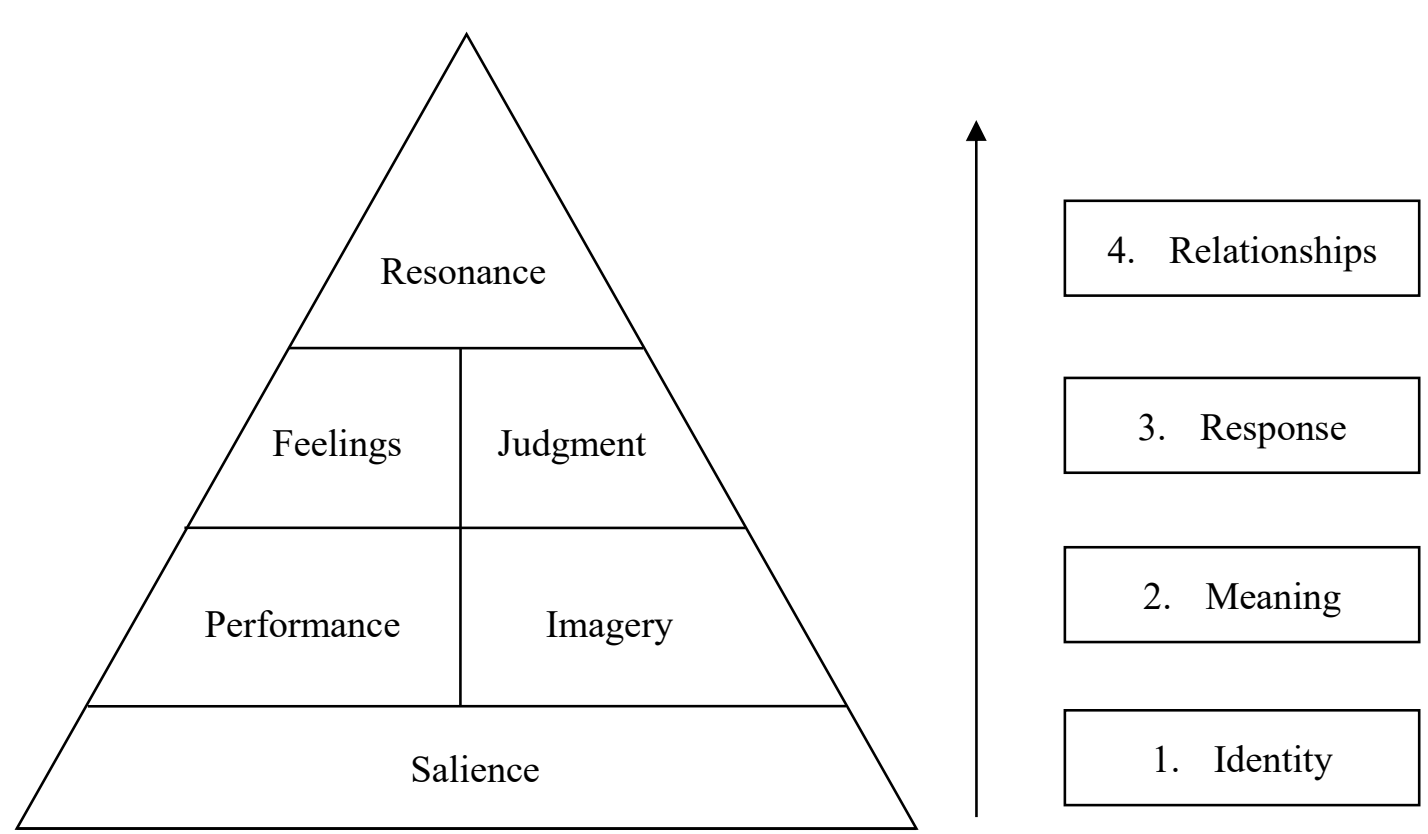

Source: Keller, 2003

Figure 1. Customer-Based Brand Equity Pyramid

\section{The Relation between Customer and Brand}

Based on the understanding of elementary steps, brand salience, of CBBE, more research can be undertaken from Olins's (2003a) description:

"The power of a brand derives from a curious mixture of how it performs and what it stands for. When a brand gets the mix right it makes us, the people who buy it, feel that it adds something to the idea of ourselves" (p16).

This description shows the reason why the people are willing to pay a premium for some well-known brands, such as Louis Vuitton and Gucci; because these brands will make them feel good, and acquire "added value with which a given brand endows a product" (Farquhar, 1989, p24), so they feel it is worth the money.

Olins (2003a) believed this phenomenon mentioned above derives from both "how it performs" functionally and "what it stands for" emotionally. The two characteristics can be explained by the brand meaning of $\mathrm{CBBE}$, the brand performance and brand imagery reflect the functional and emotional characteristics respectively (e.g. Olins 2003a; Lury 2004), or tangible and intangible attributes of a brand (Power and Hauge, 2006).

The tangible attribute can be explained by Aaker's (1992) definition, that is, the brand as a "distinguishing name and/or symbol (such as a logo, trade-mark, or package design) intended to identify the goods or services of a seller or group of sellers, and to differentiate their goods or services from those of the competitors" (p. 7). This definition focuses on measurable objective advantages of a product, and consumers can see the performance of product or service; for example, Volvo always be linked with safety due to its secure performance and design. The tangible attribute is an important element that can affect the understanding of brands by consumers, so it is the basic conditions of brands. 
The intangible attribute refers to the added value generated by brand (Kamakura and Russell, 1993; Blackston, 1992), and consumer's ideas which were acquired through a process of learning (Keller, 1993). This attribute relates to satisfaction of consumers' psychological needs about a brand, which can be used to explain the reason that some consumers buy well-known brand products though they do not need them (Berger and Ward, 2010), such as conspicuous consumption (Veblen, 1899). For example, Rolex can stand for refine, Montblanc means celebrity; the people will buy the two brands as they make them feel corresponding taste and lifestyle, so it shows psychological process also can be used to generate brand equity.

According to the discussion of tangible and intangible attribute of brand; stronger brand performance need to improve the product or service quality to satisfy the customers' functional needs; and the brand imagery can be improved through to dovetail with, even surpass customer's psychological need. Besides, the "curious mixture" in Olins's quotation is necessary; CBBE model shows the importance of the combining of brand performance and brand imagery, because "names and symbols are thus only seen as triggers of what the brand actually stands for" (Strebinger et al, 1998, p6), and brand imagery can be raised through brand performance or experience. Lastly, the development and mix of the two dimensions can build a strong, favorable, and unique brand association which is "essential as sources of brand equity to drive customer behaviour" (Leone et al, 2006, p126).

Once a brand gets the mix of the brand performance and brand imagery successfully, it will make consumers generate more self-ideas about the brand; it also means that a strong, favorable, and unique brand meaning can lead to a positive brand response. Brand response contains two important dimensions: brand judgments and brand feelings (Keller, 2003). Brand judgment refers to how consumers evaluate the brand and form their opinions based on how brand performs and what it stands for (Guzmán, 2005). Guzmán (2005) goes on to argue that "brand feelings are the customers' emotional responses and reactions to the brand" (p16). These feelings are based on many factors, which include warmth, pleasure, tension, security, social acceptance and self-respect (Keller, 2003).

According to Keller (2003), brand judgment is formed rationally, and based on three criteria: product quality, brand reliability and superiority. Take a look at Starbucks. Consumers' opinions are based on quality of product and service, price, store, promotion, etc. The Starbucks brand is always accompanied by high quality coffee, high quality service and elegant environment; and it is also perceived as a warm and friendly place, the ambience of store makes people feel comfortable and relaxed. Furthermore, many customers consider "all chains of Starbucks stores across the world deliver consistent quality and value" (Humnabadkar, 2003, p7). On the other hands, Starbucks brand can satisfy consumers' psychological and emotional needs. Dunne (2004) refers that "coffee was an affordable luxury" (p1); and many consumers consider Starbucks as a symbol of high quality lifestyle.

Brand like Virgin can almost sweep across the world. Virgin "has a cool, non-conformist image and is strongly associated with youth culture" (Forbes, 2003, p1). Therefore, consumers will buy Virgin products because this brand makes them feel young and fashionable and they hope to buy into this lifestyle. There are a number of well-known brands also use powerful and all-inclusive emotions to target a worldwide consumer, such as, BMW, KFC and Nike. Take a look at Nike, lots of athletes consider Nike shoes can help 
them perform much better and also this brand is a symbol of fashion; however, most young consumers who buy Nike shoes just think them stand for glamour and fashion; and the symbol of Nike brand can satisfy their emotional needs (Olins, 2003a). The examples mentioned above indicate that both function and symbol are important for consumers to choose the brand.

\section{Building Customer-Brand Relationship by Brand Community}

Based on discussion of Olins's quotation above and the analysis of CBBE, the connotation of Olins's quotation can be extended to the last step, brand resonance, of CBBE. It means building a relationship between brand and customer. The customer-brand relationship is very important in the research of brand loyalty (Fournier, 1998), because effective customer relationship management will lead to greater and true customer loyalty (Evans and Laskin, 1994). Starbucks brand has been doing a good job in this respect; it has a deep customer loyalty (Ledward and Moran, 2009) through make the customers feel it is one of most trusted brands (Dunne, 2004) and keep the customers happy (Gill, 2009). As the Starbucks brand has a nice development, the relationship between customer and brand can through achieve brand loyalty to maintain, enhance, protect brand (Ledward and Moran, 2009), and then improve the brand competitive advantage. Therefore, as the top of the CBBE pyramid, building relationship can be viewed as the ultimate aim and crucial step to build strong brand.

The brand community can be seen as one of useful innovative methods to build and measure the relationship between customers and brands. This viewpoint also comes from the extending of Olins's quotation, because Olins (2003b) believed the people are willing to pay a premium for some brands as they feel themselves belong to a special group. This special group develops into a brand community which is "a specialized, non-geographically bound community, based on a structured set of social relations among admirers of a brand" (Muniz and O'Guinn, 2001, p412). This concept reflects a brand-centered community based, it shows the relations among customers of a same brand are formed via the use of it, feeling about it and connection to it. A strong brand community can truly actualise relationship marketing and brand loyalty (Muniz and O'Guinn, 2001). So, the companies can use brand community to delivery brand value or add idea to customers, and measure relationship between customer and brand.

The brand value and customers' ideas of brands can be understood and generated from three markers of brand communities: shared consciousness, rituals and traditions, and a sense of moral responsibility (Muniz and O'Guinn, 2001), which are the nature of brand communities and necessary elements forming brand communities. These three markers also can lead to reactions to customers; they can give community members an insight into the meaning, culture and history of brands, discuss some problems about brands, and enhance the sense of responsibility of community members.

The concept of brand community was extended by McAlexander et al. (2002). He believed the brand community is a network based on consumers, and the consumers can provide their products experiences to the community. In this concept, the communities can exist; depend on the experiences, so it shows the importance of experience. These consumers' experiences come from interaction of members, and the interaction and experiences also help to build the brand meaning with marketers (McAlexander et al., 2002). It indicates the experiences not only affect the brand communities, but also can affect the brands. So, the 
community members can communicate and deliver brand meanings, and identify with this brand by sharing experiences, opinions and ideas. The Burberry gives customers access to upload photos of their own wearing Burberry's clothes; the experiences sharing can promote consumers' communications and attract more customers, therefore, more things are added to customers' idea.

\section{Conclusion}

In this paper, the discussion of brand connotation was based on Olins's quotation and CBBE pyramid model. In the analysis of CBBE and Olins's description, the purpose is not to make customers be aware of brands and differentiate them, but can be used to understand and research the relation between customer and brand.The deeper understanding about branding, the brand meaning and brand response of CBBE are reflected in Olins's description; it means this description includes more key elements of branding: the brand performance (tangible, functionally) and brand imagery (intangible, emotionally), and brand judgement and brand feeling. The analysis of these elements indicates "the aim of branding is to make an almost indistinguishable link between the character of an object from and its branded image or form" (Power and Hauge, 2006, p5) and some ethereal qualities also are sold with products. Lastly, with Olins's (2003b) opinions, the description was extended to the top of pyramid, the relationship between brand and customer, and brand community. It shows the deeper connotation of Olins's description; the reason that people are willing to pay a premium for some well known brands also can be explained by brand community, because they hope to be belonged a specific group, which is the key to building a strong customer-brand relationship. 


\section{References}

Aaker, D. (1992), Management des Markenwerts. Frankfurt/Main: Campus-Verlag.

American Marketing Association (AMA), www.marketingpower.com

Berger, J. \& Ward, M. (2010) Subtle Signals of Inconspicuous Consumption. Journal of Consumer Research, December.

Blackston, M. (1992). Observations: Building Brand Equity by Managing the Brand's Relationships. Journal of Advertising Research, 32 (May/June), p79-83

Cowley, D. (1991). Understanding brands, by ten people who do. London, UK: Kogan page Limited.

Dunne, D. (2004). The Starbucks Brand. Rotman School of Management Case Series. Location: University of Toronto.

Evans, J. R., \& Laskin, R. L. (1994). The relationship marketing process: A conceptualization and application. Industrial Marketing Management, 23(5), p439-452.

Farquhar, P. H. (1989). Managing Brand Equity. Marketing Research, 1 (September), p2433.

Fournier, S. (1998) Consumers and Their Brands: Developing relationship Theory in Consumer Research. Journal of Consumer Research, Vol. 24, March, p343-373.

Gill, J. (2009). The future? Wish upon a Starbucks. The Times. $5^{\text {th }}$ March.

Guzmán, F. (2005). A brand building literature review. Excerpt from PhD Thesis "Brand Building towards Social Values: Associating to Public Goods" of ESADE, ESADE.

Humnabadkar, R., Mather, J. \& Vogel, C. (2003). The Role of Design in Establishing a Brand Three In-depth Case Studies. [Online]. Available from:

http://ruchadesigns.com/final_CMU/idsa_journal.pdf [Accessed: 12 July 2010].

Kamakura, W. \& Russel, G. (1993) Measuring Brand Value with Scanner Data. International Journal of Research in Marketing, 10 (March), p9-22.

Keller, K. L. (1993). Conceptualizing, Measuring, and Managing Customer-Based Brand Equity. Journal of Marketing, 57 (January), p1-22.

Keller, K. L. (2003). Strategic Brand Management: Building, Measuring, and Managing Brand Equity, Upper Saddle River, Prentice Hall.

Kotler, P. (2000). Marketing Management. The Millennium Edition, Upper Saddle River, Prentice Hall.

Ledward, R. \& Moran, F. (2009) Economics and marketing. Dorchester: Dorset Press 
Leone, R.; Rao, V.; Keller, K.; Luo, A.; MacAlister, L. and Srivastava, R. (2006). Linking Brand Equity to Customer Equity. Journal of Service Research, Volume 9, No. 2, November, p125-138

Lury, C. (2004). Brands : the logos of the global economy. New York, Routledge.

McAlexander, J., Schouten, J., \& Koenig, H. (2002) Building brand community, Vol66, p38-54.

Muniz, A. \& O'Guinn, T. (2001). Brand community, Journal of Consumer Research, Vol 27, March, p412-432.

Olins, W. (2003a). On brand. London, Thames \& Hudson.

Olins, W. (2003b) Why brands are good for you. Times Magazine, 13 September.

Pennington, J. \& Ball, A. (2009) Customer branding of commodity products: The customer-developed brand. Brand Management, Vol. 16, 7, p455-467

Power, D. \& Hauge, A. (2006) No man's brand - Brands, institutions, fashion and the economy. Centre for Research on Innovation and Industrial Dynamics.

Strebinger, A., Schweiger, G. \& Otter,T. (1998). Brand Equity and Consumer Information Processing: A Proposed Model. Marketing Exchange Colloquium, American Marketing Association.

Veblen, T. (1899). The Theory of the Leisure Class. New York: Penguin. 